\title{
OLIGOETHEROLS WITH S-TRIAZINE RING BASED ON HYDROXYMETHYL DERIVATIVES OF METHYL ETHYL KETONE
}

\author{
Dorota Glowacz-C zerwonka1,*
}

DOI: dx.doi.org/10.23939/chcht11.01.045

\begin{abstract}
The possibility of using hydroxymethyl derivatives of methyl ethyl ketone to obtain new oligoetherols with s-triazine ring was suggested. The oligoetherols were obtained from melamine solutions in hydroxymetyl derivatives using 12 molar excess ethylene oxide. Initial tests proved that obtained oligoetherols can be a potential substrate for obtaining polyurethane foams with increased thermal stability.
\end{abstract}

Keywords: hydroxymetyl derivatives of methyl ethyl ketone, ethylene oxide, s-triazine ring, properties of oligoetherols.

\section{Introduction}

Melamine (compound with s-triazine ring) is a non-toxic and non-flammable material, more and more often used as an exquisite flame retardant [1]. A scarcity of data on melamine materials available in the literature except for melamine-formaldehyde resins) follows from the very limited solubility of melamine in organic solvents suitable for the reaction. The effective melamine solvents have been sought after for years.

The research initiated by Wirpsza and continued in Department of Organic Chemistry of Rzeszow University of Technology demonstrated that hydroxymethyl derivatives of ketones (so-called reactive solvents) can be good solvents of melamine. The material not only dissolves in this solvents, but also undergoes a chemical reaction, forming resin-like reactive system, in which (at increased temperature) polycondensation proceeds, resulting in resin formation and then gelation and curing [2-4].

The reactive melamine solvents can find application in production of water-resistant polymer coatings, filled materials and foamed polyurethane

\footnotetext{
${ }^{1}$ Rzeszow University of Technology, Faculty of Chemistry, Department of Organic Chemistry,

6, Powstancow Warszawy Ave., 35-959 Rzeszow, Poland

*dglowacz@prz.edu.pl

(C) Glowacz-Czerwonka D., 2017
}

materials [5]. The most recent applications of melamine solutions are in the field of oligoetherols [6].

So far, oligoetherols containing s-triazine ring were produced in reactions of melamine with excess of oxiranes [7] or alkylene carbonates [8] (see equation).

The solutions of melamine in hydroxymethyl derivatives of ketones (i.e. reactive solvents) can be used as the substrates for the production of oligoetherols. The oligoetherols obtained can find application in the production of self-extinguishing or non-flammable polyurethane foams.

\section{Experimental}

The reactive solvent (3-HMMEK) was obtained in the reaction of 1 mole of ethyl-methyl ketone with 3 moles of formaldehyde (introduced as formalin) in the presence of trimethylamine (TEA) as a catalyst. The reaction was carried out at the temperature of $353 \mathrm{~K}$. When the reaction was completed, water and catalyst were removed by vacuum distillation [9].

Oligoetherols were obtained in pressure reactors, by introduction of melamine solution in 3-MMMEK (obtained using 0,10 and $20 \mathrm{wt} \%$ of the solvent introduced [9]) and ethylene oxide. The pressure reactor was plugged and placed in a water bath on a magnetic stirrer. The reaction was carried out at $313-323 \mathrm{~K}$, until the reaction was completed (i.e. the mass stopped changing).

Selected physical properties (density, viscosity, surface tension) and chemical properties (content of permanently and impermanently bonded formaldehyde and hydroxyl number) were investigated.

In order to determine the structures of the products, proton magnetic resonance spectra (Bruker Avance $500 \mathrm{MHz}$ NMR Spectrometer), infrared spectra (Bruker ALPHA FT-IR Spectrometer) and elemental analysis (Elementar Vario EL III C, H, N, S and O Elemental Analyser) were taken and gas chromatography (Agilent Technologies 7890A GC System with FID detector) was performed. 
<smiles>Nc1nc(N)nc(N)n1</smiles><smiles>OCCN(CCOO)c1nc(N(CCO)CCOO)nc(N(CCO)CCOO)n1</smiles>

where: $x+y+z+p+q+m=n$

\section{Results and Discussion}

Oligoetherols were obtained from anhydrous and from water-containing (10 or $20 \mathrm{wt} \%)$ melamine solutions in 3-HMMEK, by introduction of ethylene oxide and TEA as a catalyst. The amount of oxirane used was in 12-molar excess with respect to melamine introduced (Table 1).

The temperature range of the reaction was defined based on the research performed in previous years in Department of Organic Chemistry of Rzeszow University of Technology. The lower limit followed from too small reaction rate, whereas the upper one from the risk of evaporation of low-boiling oxirane from the reaction medium (and the possibility of thickening or solidification of oligoetherol) [10].

For the selection of the reactive solvent used as a substrate for the obtaining of oligoetherols the following principles were followed:
- the hydroxymethyl derivative should be characterized by the lowest possible molar ratio of ketone to formaldehyde,

- the amount of melamine solubilized should be as high as possible, and the water content as low as possible.

For the preliminary assessment of the usefulness of the oligoetherols for the production of polyurethane foams, the surface tension and the viscosity of the obtained products were taken into account (Table 2). Surface tension is a factor determining the size and uniformity of the pores, the proper course of the foaming process, stabilization of the foams, and their mechanics. Viscosity influences stabilization of the foams.

The amount of free and permanently bonded formaldehyde was found to be close to zero (Table 2). It proves that formaldehyde was stopped from reacting with oxirane and the risk of side-reactions was excluded.

Table 1

Synthesis conditions and mass balance for the reaction of obtaining of oligoetherols

\begin{tabular}{|c|c|c|c|c|c|c|}
\hline \multirow{2}{*}{$\begin{array}{c}\text { Oligoetherol } \\
n_{M e l}: n_{E O}\end{array}$} & \multirow{2}{*}{ Synthesis time, $\mathrm{h}$} & \multicolumn{3}{|c|}{ Amount of the substrates, g/100 $\mathrm{g}$ RS } & \multirow{2}{*}{$\begin{array}{c}\text { Appearance of the } \\
\text { oligoetherol obtained }\end{array}$} \\
\cline { 2 - 7 } & & Mel, g & Water, $\mathrm{wt} \%$ & $\mathrm{TEA}, \mathrm{cm}^{3}$ & $\mathrm{EO}, \mathrm{g}$ & orange, thick resin \\
\hline \multirow{3}{*}{$1: 12$} & 55 & 20.0 & 0 & 2.4 & 84.2 & orang \\
\cline { 2 - 7 } & 77 & 36.7 & 10 & 2.4 & 195.8 & orange, thick resin \\
\cline { 2 - 7 } & 92 & 46.7 & 20 & 2.4 & 279.2 & orange, thick resin \\
\hline
\end{tabular}

Table 2

Physical and chemical properties of oligoetherols at $293 \mathrm{~K}$

\begin{tabular}{|c|c|c|c|c|c|c|c|}
\hline \multirow{3}{*}{$\begin{array}{c}\text { Oligoetherol } \\
n_{M e l}: n_{E O}\end{array}$} & \multirow{3}{*}{$\begin{array}{l}\text { Share of water } \\
\text { introduced during } \\
\text { dissolving, wt \% }\end{array}$} & \multicolumn{3}{|c|}{ Physical properties } & \multicolumn{3}{|c|}{ Chemical properties } \\
\hline & & \multirow[b]{2}{*}{$\begin{array}{l}\text { Density, } \\
\mathrm{g} / \mathrm{cm}^{3}\end{array}$} & \multirow[b]{2}{*}{$\begin{array}{c}\text { Viscosity, } \\
\mathrm{Pa} \cdot \mathrm{s}\end{array}$} & \multirow{2}{*}{$\begin{array}{c}\text { Surface } \\
\text { tension } \cdot 10^{-3}, \\
\mathrm{~N} / \mathrm{m}\end{array}$} & \multicolumn{2}{|c|}{$\mathrm{CH}_{2} \mathrm{O}$, wt $\%$} & \multirow{2}{*}{$\begin{array}{c}\text { Hydroxyl } \\
\text { number } \mathrm{L}_{\mathrm{OH}} \text {, } \\
\text { mg KOH/g }\end{array}$} \\
\hline & & & & & $\begin{array}{l}\text { sulfite } \\
\text { method }\end{array}$ & $\begin{array}{l}\text { iodometric } \\
\text { method }\end{array}$ & \\
\hline \multirow{3}{*}{$1: 12$} & 0 & 1.5589 & 6.4292 & 43.5 & 0.10 & 0.21 & 187.11 \\
\hline & 10 & 1.4552 & 4.8179 & 54.0 & 0.0 & 0.0 & 396.52 \\
\hline & 20 & 1.4029 & 2.9360 & 79.1 & 0.05 & 0.14 & 337.18 \\
\hline
\end{tabular}


During the determination of hydroxyl value, the content of hydroxyl groups was estimated. They are formed in the reactions between melamine and hydroxymethyl derivatives of methyl ethyl ketone (i.e. reactive solvent) and next with ethylene oxide.

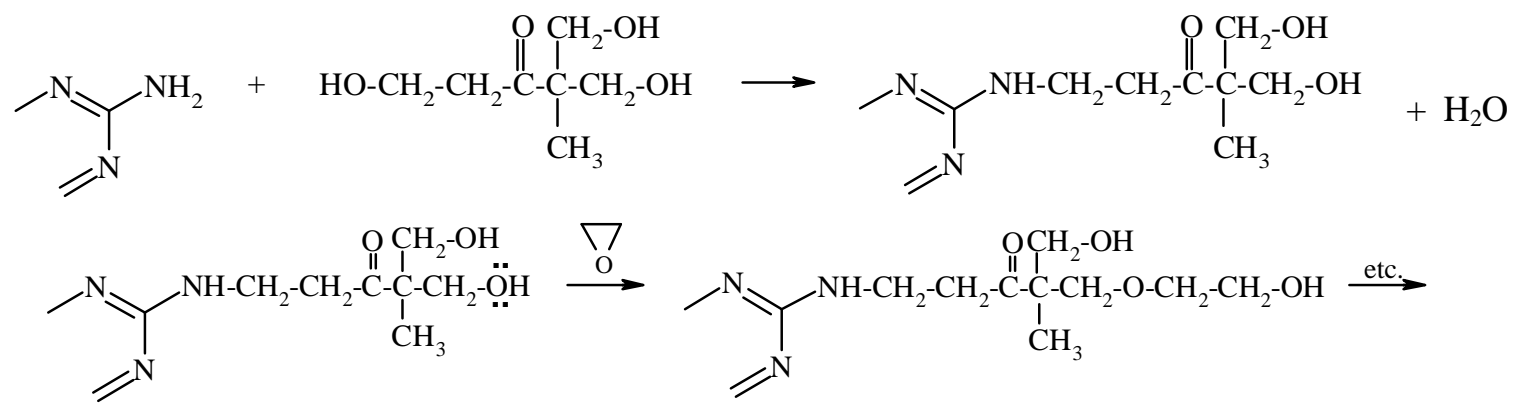

Table 3

Elemental analysis of oligoetherols

\begin{tabular}{|c|c|c|c|c|c|c|c|}
\hline \multirow{2}{*}{$\begin{array}{c}\text { Oligoetherol } n_{M e l} \\
: n_{E O}\end{array}$} & \multirow{2}{*}{$\begin{array}{c}\text { Share of water } \\
\text { introduced during } \\
\text { dissolving, wt \% }\end{array}$} & \multicolumn{3}{|c|}{ C } & \multicolumn{3}{|c|}{ Elemental analysis, wt \% } \\
\cline { 3 - 8 } & & Calc. & Determ. & Calc. & Determ. & Calc. & Determ. \\
\hline \multirow{3}{*}{$1: 12$} & 0 & 46.19 & 46.47 & 9.31 & 9.38 & 7.54 & 7.19 \\
\cline { 2 - 8 } & 10 & 46.10 & 46.41 & 8.86 & 8.86 & 7.47 & 7.09 \\
\cline { 2 - 8 } & 20 & 46.70 & 46.70 & 8.96 & 9.00 & 6.60 & 6.89 \\
\hline
\end{tabular}

Table 4

The content of the products of secondary reactions in the final product

\begin{tabular}{|c|c|c|c|c|c|}
\hline \multirow{2}{*}{$\begin{array}{c}\text { Oligoetherol } \\
n_{M e l}: n_{E O}\end{array}$} & \multirow{2}{*}{$\begin{array}{c}\text { Share of water } \\
\text { introduced during } \\
\text { dissolving, wt \% }\end{array}$} & \multicolumn{4}{|c|}{ The amount of by-products in oligoetherol, wt \% } \\
\hline & & EG & DEG & TRIEG & TETRAEG \\
\hline \multirow{3}{*}{$1: 12$} & 0 & 8.05 & 6.15 & 0.85 & 0.0 \\
\hline & 10 & 3.64 & 7.98 & 8.15 & 3.89 \\
\hline & 20 & 2.65 & 5.71 & 9.66 & 11.07 \\
\hline
\end{tabular}

The structure of the reactive solvent (3-HMMEK) and oligoetherols was found based on ${ }^{1} \mathrm{H}$ NMR and IR spectra and elemental analysis (Table 3).

The oligoetherols obtained from ethylene oxide and melamine solutions were analyzed using chromatography (GC) in order to estimate the content of by-products (formed in the reaction of ethylene oxide with water, present in the melamine solution in 3-HMMEK). The byproducts are ethylene glycol (EG) as well as diethylene, triethylene and tetraethylene glycols (DEG, TRIEG and TETRAEG, respectively) formed in the secondary reaction of EG with 1, 2 and 3 moles of etylene oxide (EO).

The content of glycols in the obtained oligoetherols is not high and higher amounts of the products of secondary reactions were found in the oligoetherols obtained in the presence of water (introduced during solubilization of melamine, Table 4).

Based on the results obtained, it was found that the synthesized oligoetherols can be a prospective polyol component for obtaining of polyurethane foams of increased thermal stability.

\section{Conclusions}

The oligoetherols have been obtained from melamine solutions in a reactive solvent and 12-mole excess of ethylene oxide. The structure of the oligoetherols obtained has been confirmed by ${ }^{1} \mathrm{H}-\mathrm{NMR}$, IR and elemental analysis. Selected physical and chemical properties of the oligoetherols obtained have been investigated. The properties are in the region typical of the polyols used for polyurethane foams production. The amount of byproducts was determined on the basis of chromatographic analysis. An increase of the amount of by-products was observed while increasing the amount of water introduced into melamine while its dissolving in hydroxymethyl derivative of methyl ethyl ketone. Owing to the presence of an s-triazine ring, the synthesized oligoetherols can be a 
prospective polyol component for obtaining of polyurethane foams of increased thermal stability.

\section{References}

[1] Wirpsza Z.: Polimery, 1996, 41, 265.

[2] Wirpsza Z., Kucharski M. and Lubczak J.: J. Appl. Polym. Sci., 1998, 67, 1039.

[3] Wirpsza Z., Kucharski M., Lubczak J. et al.: Pat. PL 313669, Publ. Oct. 13, 1997.

[4] Glowacz-Czerwonka D. and Kucharski M.: J. Appl. Polym. Sci., 2005, 95, 1319.

[5] Glowacz-Czerwonka D.: CHEMIK, 2013, 67, 289.

[6] Glowacz-Czerwonka D. and Lubczak J.: Pat. Appl. PL No. P-400524, Publ. Aug. 27, 2012.

[7] Kucharski M. and Lubczak J.: Acta Polym., 1991, 42, 186.

[8] Kucharski M. and Kijowska D.: J. Appl. Polym. Sci., 2003, 89, 104.

[9] Glowacz-Czerwonka D. and Kucharski M.: J. Appl. Polym. Sci., 2006, 100, 1496
[10] Kucharski M., Lubczak J., Chmiel E. and Kopecka B.: Sci. J. Rzeszow Univ. Technol., 1990, 41, 23.

Received: January 08, 2016 / Revised: February 17, 2016 / Accepted: J une 12, 2016

\section{ОЛІГОЕСТЕРОЛИ 3 S-ТРИАЗИНОВИМ КІЛЬЦЕМ НА ОСНОВІ ГІДРОКСИМЕТИЛЬНИХ ПОХІДНИХ МЕТИЛЕТИЛКЕТОНУ}

Анотація. ППказана можливість використання гідроксиметильних похідних метилетилкетону для отримання нових олігоестеролів з s-триазиновим кільцем. Одержано олігоестери з меламінових розчинів гідроксиметильних похідних з використанням 12-ти молярного надлишку оксиду етилену. Встановлено, що отримані олігоестероли можуть бути потенційним субстратом для отримання пінополіуретанів з підвищеною термічною стабільністю.

Ключові слова: гідроксиметильні похідні метилетилкетону, оксид етилену, s-триазинове кільце, властивості олігоестеролів. 